\title{
Hubungan Antara Konsep Diri Dan Regulasi Diri Terhadap Tingkat Prokrastinasi Mahasiswa Pendidikan Agama Islam
}

\author{
Efrida Mandasari Dalimunthe ${ }^{1}$, Muhammad Ihsan \\ Email: mandasariefrida88@gmail.com,mhd.ihsanfd@yahoo.co.id
}

\begin{abstract}
This study aims to determine the relationship between self-concept and selfregulation with procrastination in student. This research uses correlational quantitative desigan. The sample used amounted 77 of the population 729 student with purposive sampling technique. The data analysis technique with multiple regression. The results showed that a positive relationship between the self-concept and self-regulation was positively linked to the procratation of students. This is indicated by the coefficient of Freg $=58,654$ where $p<0.05$. This indicates that self-concept and self-regulation are significantly linked to academic procrastination, the higher the value of self-concept and selfregulation, the lower the academic procrastination. Conversely, the lower the value of self-concept and self-regulation, the higher the academic procrastination.
\end{abstract}

Keywords: Procrastination, Self-Concept, Self-Regulation

\begin{abstract}
Abstrak
Penelitian ini bertujuan untuk mengetahui hubungan antara konsep diri dan regulasi diri dengan prokratinasi. Penelitian ini menggunakan desain kuantitatif korelational. Sampel yang digunakan 77 dari populasi 729 mahasiswa dengan teknik pengambilan sampel purposive sampling. Adapun teknik analisis data menggunakan regresi linear berganda. Hasil penelitian menunjukkan adanya hubungan positf antara konsep diri dan regulasi berhubungan positif dengan prokratinasi mahasiswa. Hal ini ditunjukkan dengan koefisien $\mathrm{F}_{\text {reg }}=58,654$ dimana $\mathrm{p}<0,05$. Ini menandakan Konsep Diri dan Regulasi Diri berhubungan signifikan dengan prokrastinasi akademik, semakin tinggi nilai Konsep Diri dan Regulasi Diri maka prokrastinasi akademik akan semakin rendah. Sebaliknya semakin rendah nilai Konsep Diri dan Regulasi Diri,, maka prokrastinasi akademik akan semakin tinggi.
\end{abstract}

Kata Kunci: Prokrastinasi, Konsep Diri, Regulasi Diri

\section{PENDAHULUAN}

Saat ini, kualitas Sumber Daya Manusia (SDM) memegang peranan penting untuk menentukan dalam memacu pertumbuhan berbagai bidang. Untuk itu maka penekanan yang sangat kuat terhadap peningkatan kualitas sumber daya manusia menunjukkan komitmen bangsa yang sangat besar untuk mengejar keunggulan dalam era persaingan global. Tidak dapat

\footnotetext{
${ }^{1}$ Dosen Institut Agama Islam Negeri Padangsidimpuan
} 
dipungkiri bahwa kemajuan suatu bangsa sangat bergantung pada kualitas manusia yang ada di negara tersebut khususnya generasi muda. Salah satu jalur strategis yang dapat digunakan untuk mewujudkan sumber daya manusia (SDM) yang berkualitas adalah jalur pendidikan.

Mahasiswa dapat dikatakan sebagai kelompok dari generasi muda yang sedang belajar atau menuntut ilmu di perguruan tinggi, dengan jurusan atau program tertentu, aktivitas mereka adalah belajar. Belajar ilmu pengetahuan, belajar berorganisasi, belajar bermasyarakat dan belajar menjadi pemimpin. Kelompok ini menyandang sejumlah atribut di antaranya sebagai kelompok inti pemuda, kelompok cendikia, atau golongan intelektual, calon pemimpin masa depan, manusia idealis dan kritis karena di pundak mahasiswa sebagian besar nasib masa depan suatu bangsa dipertaruhkan.

Seseorang dikatakan mempunyai kualitas sumber daya manusia yang tinggi jika dia dapat menunjukkan perilaku yang mencerminkan adanya kedisplinan, kreativitas maupun etos kerja yang tinggi dalam mengerjakan tugas-tugasnya. Sikap disiplin merupakan sikap yang harus ditingkatkan, karena memberikan manfaat dan sumbangan yang besar, apalagi pada negara yang masih berkembang seperti negara Indonesia. Menurut Prayitno di antara salah satu faktor penentu kesuksesan mahasiswa di perguruan tinggi adalah sejauh mana mahasiswa tersebut mampu menyelesaikan dengan baik tugas-tugas yang diberikan oleh dosen dengan baik dan tepat waktu. ${ }^{2}$ Jika dicermati, sebenarnya mahasiswa berada pada masa-masa produktif ini. Seiring berjalannya waktu, terdapat hal-hal penting yang mulai bergeser dari budaya dan kewajiban mahasiswa seharusnya. Hal yang paling kentara dewasa ini adalah budaya menunda-menunda kewajiban sebagai mahasiswa atau yang sering disebut dengan istilah "prokrastinasi". Hal inilah yang mungkin tidak bisa disangkal, prokrastinasi dalam kondisi awal dapat mengurangi stres seseorang ketika mendapatkan tugas atau kewajiban yang sebenarnya tidak di inginkannya atau mungkin sulit untuk dapat diselesaikan. Sebab individu akan berhenti untuk memikirkan hal-hal yang memberatkan pikirannya tersebut, namun yang perlu dicermati adalah perilaku seperti ini malah akan menjadi suatu bumerang. Sebab dalam kondisi selanjutnya stres itu akan memuncak melebihi stres yang dihadapi individu dikondisi awal, yaitu ketika individu dikejar deadline dalam mengumpulkan tugas yang telah diberikan. Akibatnya tugas yang diberikan menjadi terbengkalai dan jauh dari kesan yang diinginkan.

2 Prayitno, Keterampilan Belajar, Tim Pengembangan 3 SCPD Proyek PGSM. Depdikbud, Jakarta (2002): 62. 
Perilaku menunda untuk memulai mengerjakan dan menyelesaikan sesuatu disebut dengan prokrastinasi, dan orang yang melakukan perilaku menunda disebut penunda (procrastinator). Gejala perilaku menunda (prokrastinasi) lebih banyak dimanifestasikan dalam dunia pendidikan yang sering disebut dengan prokrastinasi akademik. Prokrastinasi akademik sendiri terjadi karena adanya keyakinan irasional yang dimiliki oleh seseorang. Keyakinan irasional tersebut dapat disebabkan oleh suatu kesalahan dalam mempersepsikan tugas akademik, seseorang memandang tugas sebagai sesuatu yang berat dan tidak menyenangkan.

Ji Won Youdi dalam penelitiannya menyebutkan bahwa dari 569 orang mahasiswa yang diteliti, 56,39\% melakukan prokrastinasi akademik. Prokrastinasi akademik yang dilakukan mengarah kepada hal-hal yang bersifat menyenangkan seperti menonton film hingga berjam-jam, games online, kegiatan ini lebih disenangi daripada mengerjakan tugas akademik, sehingga terdapat keterlambatan dalam mengumpulkan tugas perkuliahan. ${ }^{3}$

Ada banyak kasus perilaku prokrastinasi akademik yang dialami oleh siswa, tetapi dampak negatifnya, kehilangan diri atau kehilangan pada orang lain belum terwujud dengan baik. Hasil penelitian yang dilakukan oleh Juliawati pada tahun 2014 di sebuah sekolah di kota Padang menunjukkan bahwa kecenderungan untuk menunda sekolah siswa dengan persentase 60\% (kategori tinggi), kemudian dengan persentase 20\% (kategori sedang) dan 20\% (kategori rendah). Berdasarkan hasil tersebut, bahwa kebiasaan menunda tugas yang tidak bertujuan adalah hal yang biasa dilakukan oleh siswa. ${ }^{4} \mathrm{Hal}$ ini juga dapat disejajarkan dengan kebiasaan mahasiswa yang berkaitan dengan beban SKS yang diperolehnya, biasanya dibelokkan kepanjangannya dengan sistem kebut semalam. Dapat dibandingkan antara pelajar SMU/SMA dan yang sederajat dengan mahasiswa, apalagi pada level mahasiswa yang lebih banyak beban tugas, tanggungjawab, dan aktivitas-aktivitas lain baik yang bersifat akademik maupun nonakademik, ditambah lagi mereka juga dituntut untuk memulai mencari peluang di suatu lapangan pekerjaan.

Prokrastinasi akademik juga memiliki beberapa faktor yang berkorelasi dengan manajemen waktu yang buruk, lokus kendali diri, perfeksionis, takut gagal, dan menghindari tugas. Manajemen waktu dan prokrastinasi akademik berkorelasi negatif dan signifikan.

\footnotetext{
${ }^{3} \mathrm{Ji}$ Won You. Examining the Effect of Academic Procrastination on Achievement Using LMS Data in e-Learning.Journal of Educational Technology and Society, Vol. 18, No. 3 (2015):64-74

4 Syaiful Indra, Efektifitas Team Assisted Individualization untuk Mengurangi Prokrastinasi Akademik, Jurnal Edukasi, Vol I, Nomor 2, (Juli 2015):175
} 
Manajemen waktu sangat berkaitan erat dengan regulasi diri dan konsep diri. Dengan konsep diri yang baik, maka secara otomatis regulasi diri juga akan terindikasi baik. Sehingga sifat penundaan dapat secara otomatis terminimalisir.

Pengelolaan waktu yang baik akan berpengaruh terhadap hasil belajar yang optimal dan prestasi dapat dicapai salah satunya melalui kemampuan untuk mengatur dirinya dalam kegiatan sehari-harinya. Mahasiswa perlu untuk mengorganisir dirinya sehingga dengan kondisi yang seperti itu, mereka mampu menjalani dan bahkan bisa mencapai hasil yang optimal. Di dalam proses belajar, seseorang akan memperoleh prestasi belajar yang baik bila ia menyadari, bertanggungjawab dan mengetahui cara belajar yang efisien. Hal ini tentu membutuhkan pengaturan diri yang baik atau dengan kata lain, regulasi diri.

Regulasi diri dibutuhkan dalam proses pengembangan diri. Regulasi Diri menurut Bandura adalah suatu kemampuan yang dimiliki manusia berupa kemampuan berfikir, dan dengan kemampuan itu mereka memanipulasi lingkungan, sehingga terjadi perubahan lingkungan akibat kegiatan tersebut. Menurut Bandura seseorang dapat mengatur sebahagian dari pola tingkah laku dirinya sendiri. Secara umum regulasi diri adalah tugas seseorang untuk mengubah respon- respon, seperti mengendalikan impuls perilaku (dorongan perilaku), menahan hasrat, mengontrol pikiran dan mengubah emosi. Maka dengan kata lain, regulasi diri adalah suatu kemampuan yang dimiliki oleh individu dalam mengontrol, dan memanipulasi sebuah perilaku dengan menggunakan kemampuan pikirannya sehingga individu dapat bereaksi terhadap lingkungannya. Individu bereaksi terhadap lingkungannya terjadi secara reaktif dan proaktif dalam regulasi diri. Strategi reaktif dipakai untuk mencapai tujuan, namun ketika tujuan hampir tercapai strategi proaktif menentukan tujuan baru yang lebih tinggi. Orang akan memotivasi dan membimbing tingkah lakunya sendiri melalui strategi proaktif.

Sebagai sebuah konstruk psikologi, konsep diri didefinisikan secara berbeda oleh para ahli. Konsep diri sebagai "suatu pemahaman mengenai diri atau ide tentang konsep diri. Selanjutnya konsep diri juga diartikan pandangan individu mengenai siapa diri individu, dan itu bisa diperoleh lewat informasi yang diberikan orang lain pada diri individu. Berdasarkan pada beberapa definisi di atas dapat disimpulkan bahwa konsep diri adalah gagasan tentang konsep diri yang mencakup keyakinan, pandangan dan penilaian seseorang terhadap dirinya sendiri. Konsep diri terdiri atas bagaimana cara kita melihat konsep diri sebagai pribadi, bagaimana kita merasa tentang konsep diri, dan bagaimana kemampuan berpikir seseorang. Setelah terinstall, 
konsep diri akan masuk kepikiran bawah sadar dan akan berpengaruh terhadap tingkat kesadaran seseorang pada suatu waktu. Semakin baik atau positif konsep diri seseorang maka akan semakin mudah ia mencapai keberhasilan. Sebab, dengan konsep diri yang baik/positif, seseorang akan bersikap optimis, berani mencoba hal-hal baru, berani sukses dan berani pula gagal, penuh percaya diri, antusias, merasa diri berharga, berani menetapkan tujuan hidup, serta bersikap dan berpikir secara positif. Sebaliknya, semakin jelek atau negatif konsep diri, maka akan semakin sulit seseorang untuk berhasil. Sebab, dengan konsep diri yang negatif akan mengakibatkan tumbuh rasa tidak percaya diri, takut gagal sehingga tidak berani mencoba hal-hal yang baru dan menantang, merasa diri bodoh, rendah diri, merasa diri tidak berguna, pesimis, serta berbagai perasaan dan perilaku inferior lainnya. Bukan hanya itu winarno surakhamad juga mengatakan bahwa, konsep diri murpakan cara pandang seseorang terhadap diri sendiri dan apakah cita-cita hidup mereka. Dengan ini dapat dilihat apakah konsep diri sejalan dengan harapan agar mereka berkembangan menjadi manusia dewasa, calon warga negera yang dapat diharapkan menjadi unsur penting didalam pembangunan. ${ }^{5}$

Berdasarkan penjelasan di atas, dan mengingat belum adanya penelitian yang berkaitan dengan prokrastinasi di IAIN Sumatera Utara, maka peneliti memfokuskan masalah dalam pembahasan ini diarahkan kepada studi tentang Hubungan Antara Konsep Diri dan Regulasi Diri dengan Prokrastinasi pada Mahasiswa Fakultas Ilmu Tarbiyah dan Keguruan IAIN-SU Medan Tahun Pelajaran 2014/2015.

\section{KAJIAN TEORI}

Istilah prokrastinasi berasal dari bahasa latin procrastination dengan awalan "pro" yang bararti mendorong maju atau bergarak maju dan akhiran "crastinus" yang berarti keputusan hari esok. Jika di gabungkan menjadi "menangguhkan" atau "menunda sampai hari berikutnya". Milgram menyebutkan bahwa prokrastinasi dilakukan semata-mata untuk melengkapi tugas secara optimal. Namun penundaan itu tidak membuat tugas lebih baik, hal itu mengarah pada penundaan yang tidak berguna. ${ }^{6}$

Pada akhirnya, penundaan atau penghindaran tugas yang kemudian disebut prokrastinasi tidak selalu diartikan sama dalam perspektif budaya dan bahasa manusia. Misalnya pada bangsa

\footnotetext{
${ }^{5}$ Winarno Surakhmad, Psikologi Pemuda, Bandung :Jemmars (1997), 40

${ }^{6}$ Milgram, N, Procrastination, Encyclopedy of Human Biology, New York: Academic Press, (1991):57.
} 
Mesir kuno mengartikan prokrastinasi dengan dua arti, yaitu menunjukkan suatu kebiasaan yang berguna untuk menghindari kerja yang penting dan usaha yang implusif, juga menunjukkan suatu arti kebiasaan yang berbahaya akibat kemalasan dalam menyelesaikan suatu tugas yang penting untuk nafkah hidup, seperti mengerjakan ladang ketika waktu menanam sudah tiba. Jadi pada abad lalu prokrastinasi bermakna positif bila penunda sebagai upaya konstruktif untuk menghindari keputusan implusif dan tanpa pemikiran yang matang, dan bermakna negatif bila dilakukan karena malas atau tanpa tujuan yang pasti.

Pada kalangan ilmuan, istilah prokrastinasi di gunakan untuk menunjukan suatu kecenderungan menunda-nunda penyelesaian suatu tugas atau pekerjaan. Seseorang mempunyai kecenderungan untuk menunda atau tidak segera memulai pekerjaan, ketika menghadapi suatu pekerjaan dan tugas di sebut seseorang yang melakukan prokrastinasi. Tidak peduli apakan penundaan terdsebut mempunyai alasan atau tidak. Setiap penundaan dalam menghadapi suatu tugas disebut prokrastinasi. Seseorang dikatakan melakukan prokrastinasi apabila ia menunjukkan ciri-ciri antara lain takut gagal, impulsif, perfeksionis, pasif dan menundamenunda sehingga melebihi tenggat waktu. ${ }^{7}$

Prokrastinasi berhubungan dengan berbagai sindrom-sindrom psikiatri. Seorang prokrastinator biasanya juga mempunyai pola tidur yang tidak sehat, mempunyai depresi yang kronis, penyebab stress, dan penyebab penyimpangan psikologis lainnya. Selain itu prokrastinasi juga mempunyai hubungan paradoksal terhadap bimbingan dan konseling. Solomon dan Rothblum mengatakan penundaan adalah penundaan mulai bekerja atau selesaikan tugas yang disengaja. dari definisi ini dapat dilihat bahwa perilaku prokrastinasi adalah perilaku yang disengaja, yang berarti bahwa faktor-faktor yang menunda penyelesaian tugas berasal dari keputusan itu sendiri. ${ }^{8}$

Jadi seseorang yang melakukan prokrastinasi tidak bermaksud untuk menghindari atau tidak mau tahu dengan tugas yang di hadapi. Akan tetapi, mereka hanya menunda-nunda untuk mengerjakannya sehingga menyita waktu yang di butuhkan untuk menyelesaikan tugas. Penundaan tersebut menyebabkan seseorang gagal menyelesaikan tugas tepat waktu. Seorang prokratinator memiliki pandangan bahwa suatu tugas harus diselesaikan dengan sempurna,

7 Randy Moore, Academic Procrastination and Course Performance among Developmental Education Students, Journal Research and Teaching in Developmental Education, Vol. 24, No. 2 (2008):56-67.

8 Surijah, E, \& Sia, T, "Mahasiswa Versus Tugas : Prokrastinasi Akademik Dan Conscientiousness", Anima, Indonesian Psychological Journal, Vol. 22, No. 4, (2007): 356. 
sehingga dia merasa lebih aman untuk tidak melakukannya dengan segera, karena itu akan menghasilkan sesuatu yang tidak maksimal, dengan kata lain penundaan yang dikategorikan sebagai prokrastinasi adalah apabila penundaan tersebut sudah merupakan kebiasaan atau pola yang menetap yang selalu dilakukan seseorang ketika menghadapi suatu tugas, dan penundaan tersebut disebabkan oleh adanya keyakinan-keyakinan yang irrasional dalam memandang tugas. Prokrastinator sebenarnya sadar bahwa dirinya menghadapi tugas-tugas yang penting dan bermanfaat bagi dirinya (sebagai tugas yang primer), akan tetapi dengan sengaja menunda-nunda secara berulang-ulang (komplusif), hingga muncul perasaan tidak nyaman, cemas dan merasa bersalah dalam dirinya.

Berdasarkan uraian di atas dapat ditarik kesimpulan bahwa prokrastinasi dapat didefinisikan sebagai suatu penundaan yang dilakukan secara sengaja dan berulang-ulang, dengan melakukan aktifitas lain yang tidak diperlukan dalam pengerjaan tugas. Pelaku prokrastinasi di sebut prokrastinator. Seorang prokrastinator biasanya sadar bahwa dirinya menghadapi tugas - tugas yang penting dan bermanfaat (sebagi tugas primer). Akan tetapi dengan sengaja menunda-nunda secara berulang-ulang (kompulsif), sehingga muncul perasaan tidak nyaman, cemas dan merasa bersalah dalam dirinya.

Konsep diri merupakan keseluruhan yang dirasa dan diyakini benar oleh seseorang mengenai dirinya sebagai individu ;ego dan hal-hal yang dilibatkan di dalamnya. Konsep diri akan memberikan pengaruh terhadap proses berpikir, perasaan, keinginan, nilai maupun tujuan hidup seseorang. ${ }^{9}$ Konsep diri (self concept) adalah evaluasi individu mengenani diri sendiri; penilaian atau penaksiran mengenai diri sendiri oleh individu yang bersangkutan. Calhaun dan Acocella mengungkapkan bahwa konsep diri adalah pandangan diri anda tentang anda sendiri yang meliputi tiga dimensi yakni: (1) pengetahuan atau apa yang diketahui tentang dirinya sendiri, (2) pengha- rapan mengenai dirinya dan pengharapan ini merupakan diri ideal, dan (3) penilaian tentang dirinya sendiri. ${ }^{10}$

${ }_{9}$ Clemes, H., Bean, R, “Membangkitkan Harga Diri Anak, Alih bahasa: Anton Adiwiyoto", Jakarta: Mitra Utama. (2001):2.

${ }^{10}$ Colhoun, J.F. \& Ococella, J.R, "Psychology of Adjusment an Human Relationship", Terj. Satmiko, R.S Semarang : IKIP Semarang Press, (1990):67. 
Senada dengan hal tersebut, Santrock mengungkapkan bahwa konsep diri merupakan evaluasi terhadap domain yang spesifik dari diri. ${ }^{11}$ Individu dapat membuat evaluasi diri terhadap berbagai domain dalam hidup akademiknya. Surya juga menjelaskan konsep diri adalah gambaran, cara pandang, keyakinan, pemikiran, dan perasaan terhadap apa yang dimiliki individu tentang dirinya sendiri meliputi kemampuan, karakter, sikap, perasaan, penampilan dan tujuan hidup yang dimiliki. ${ }^{12}$

Konsep diri juga dapat dikatakan sebagai kerangka acuan (frame of reference) dalam berinteraksi dengan lingkungan. Brooks (1974: 40) mendefinisikan konsep diri adalah "those physical, social, and psychological perceptions of ourselves that we have derived from experiences and our inteaction with others" atau persepsi fisis, sosial, dan psikologis tentang dirinya sendiri yang ia dapat melalui pengalaman dan interaksi dengan orang lain. ${ }^{13}$

Jadi konsep diri yang dimaksud merupakan gambaran deskriptif semata,akan tetapi juga penilaian seorang individu mengenai dirinya sendiri, sehingga konsep diri merupakan sesuatu yang difikirkan dan dirasakan oleh seorang individu. Ia mengemukakan dua komponen konsep diri yaitu, komponen kognitif (self image) dan komponen afektif( self esteem). Kemampuan Kognitif (self image) merupakan pengetahuan individu terhadap dirinya, yang mencakup pengetahuan "who am I ", dimana hal ini akan memberikan gambaran sebagai pencitraan diri. Adapun komponen afektif merupakan penilaian individu terhadap dirinya yang akan membentuk bagaimana penerimaan diri dan harga diri individu yang bersangkutan.

Dari beberapa defenisi yang telah diuraikan, dapat disimpulkan bahwa konsep diri merupakan sikap,perasaan, dan pandangan individu terhadap dirinya sebagai hasil dari interaksi dengan lingkungannya yang meliputi fisik,psikis,sosial aspirasi dan prestasi yang nantinya akan menentukan langkah-langkah individu dalam melakukan aktifitas sesuai dengan gambaran yang ada pada dirinya. Konsep diri merupakan gabungan dari keyakinan yang dimiliki tentang diri mereka sendiri secara luas baik mengenai fisik, psikologis, sosial dan emosional.

Regulasi diri adalah suatu sistem dari pribadi sadar seseorang. Misalkan seorang dokter dapat saja memberikan obat pada seorang pasien, dan memberikan nasihat-nasihat yang harus ia

${ }^{11}$ Santrock, W. J, “Adolescence: Perkembangan Remaja, Terjemahan oleh Shinto B. Adelar \& Sherly Saragih", Jakarta : Erlangga, (2003) : 56.

${ }^{12}$ Surya, H, "Percaya Diri itu Penting : Peran Orangtua dalam Menumbuhkan Percaya Diri Anak", Jakarta : Elex Media Komputindo (2007):3.

${ }^{13}$ Brooks, W. D , "Speech Communication”, Dubuque: Wm. C. Brown Company Publishers. (1974) : 40 
lakukan dalam proses penyembuhan. Oleh karena itu, pasien dengan bebas memonitor perilakunya dan mengevaluasi perilaku apa saja yang dapat memberikan pengaruh pada kesehatannya. Diaz, Neal \& AmayaWilliams mengatakan bahwa regulasi diri dapat didefinisikan sebagai kapasitas siswa untuk merencanakan, memandu, dan mengawasi perilakunya sendiri dari dalam dan bersifat fleksibel sesuai dengan perubahan kondisi. ${ }^{14}$

Regulasi diri juga merupakan suatu kemampuan yang dimiliki manusia berupa kemampuan berfikir dan dengan kemampuan itu mereka memanipulasi lingkungan, sehingga terjadi perubahan lingkungan akibat kegiatan tersebut. Menurut Bandura seseorang dapat mengatur sebahagian dari pola tingkah laku dirinya sendiri. Secara umum regulasi diri adalah tugas seseorang untuk mengubah respon-respon, seperti mengendalikan impuls perilaku (dorongan perilaku), menahan hasrat, mengontrol pikiran dan mengubah emosi Maka dengan kata lain, regulasi diri adalah suatu kemampuan yang dimili oleh individu dalam mengontrol tingkah laku, dan memanipulasi sebuah perilaku dengan menggunakan kemampuan pikirannya sehingga individu dapat bereaksi terhadap lingkungannya.

Regulasi diri (self regulation) adalah kemampuan untuk mengontrol perilaku sendiri. Regulasi diri merupakan penggunaan suatu proses yang mengaktivasi pemikiran, perilaku dan perasaan yang terus menerus dalam upaya untuk mencapai tujuan. Individu melakukan pengaturan diri ini dengan mengamati, mempertimbangkan, memberi ganjaran atau hukuman terhadap perilakunya sendiri. System pengaturan diri ini berupa standar-standar bagi tingkah laku seseorang dan kemampuan mengamati diri, menilai diri sendiri, dan memberikan respon terhadap diri sendiri.

Regulasi diri (self regulation) juga merupakan dasar dari proses sosialisasi karena berhubungan dengan seluruh domain yang ada dalam perkembangan fisik, kognitif, social, dan emosional. ${ }^{15}$ Selain itu regulasi diri (self regulation) juga merupakan kemampuan mental serta pengendalian emosi. Seluruh perkembangan kognitif, fisik, serta pengendalian emosi dan

${ }^{14}$ Diaz, R.M, Neal, C. J, \& Amaya-Williams, M, "The social origins of selfregulation", Dalam L.C. Moll (Ed). Vygotsky and education: instructional implications of sociohistorical psychology (pp 127-154). Victoria: Cambridge University Press, (1990):130

15 Schunk, D.H, "Teori-teori pembelajaran: perspektif pendidikan", (terjemahan Eva Hamdiah \& Rahmat Fajar). Yogayakarta: Pustaka, (2012): 560 
kemampuan sosialisasi yang baik, membawa seseorang untuk dapat mengatur dirinya dengan baik. ${ }^{16}$

Selanjutnya terdapat definisi lain yang diungkapkan oleh Miller \& Brown (dalam Papalia \& Olds, 2001) bahwa Regulasi diri atau regulasi diri sebagai kapasitas untuk merencanakan, mengarahkan, dan memonitor prilaku fleksibel untuk mengubah keadaan. Regulasi diri adalah kemampuan seseorang untuk menyesuaikan perilaku mereka agar sesuai dengan apa yang mereka ketahui sehingga dapat diterima oleh lingkungan sosialnya. Menurut Winne bahwa setiap orang akan berusaha meregulasi fungsi dirinya dengan berbagai cara untuk mencapai tujuan yang telah ditetapkan. ${ }^{17}$

Definisi lain mengenai regulasi diri (self regulation) juga dikemukakan oleh Maes \& Gebhardt yaitu suatu urutan tindakan atau suatu proses yang mengatur tindakan dengan niat untuk mencapai suatu tujuan pribadi. Regulasi diri merupakan kemampuan mengontrol perilaku sendiri adalah salah dari sekian penggerak utama kepribadian manusia. ${ }^{18}$

Secara umum regulasi diri adalah tugas seseorang untuk mengubah respon-respon, seperti mengendalikan impuls perilaku (dorongan perilaku), menahan hasrat, mengontrol pikiran dan mengubah emosi. ${ }^{19}$ Maka dengan kata lain, regulasi diri adalah suatu kemampuan yang dimiliki oleh individu dalam mengontrol, dan memanipulasi sebuah perilaku dengan menggunakan kemampuan pikirannya sehingga individu dapat bereaksi terhadap lingkungannya.

Teori regulasi diri merupakan salah satu perkembangan dari teori sosial kognitif. Berdasarkan teori sosial kognitif, manusia dikenal sebagai makhluk yang dapat mengorganisasi dirinya sendiri (self-organizing), proaktif, self-reflecting, dan mampu meregulasi dirinya sendiri, bukan makhluk yang reaktif, yang dibentuk dan dipengaruhi semata-mata oleh kekuatan lingkungan atau impuls-impuls dari dalam diri.

Kemampuan regulasi diri merupakan hasil dari adanya sense of personal agency, yaitu rasa dimana seseorang menganggap dirinya bertanggung jawab atas usaha pencapaian hasil. Maka dari itu ia membuat pilihan, membuat rencana untuk tindakan, memotivasi dan mengatur

\footnotetext{
${ }^{16}$ Friedman, Howard S \& schustack, Miriam W. “Kepribadian Teori Klasik Dan Riset Modern”, Edisi 3. Erlangga, (2006):276

${ }_{17}$ Boekaerts, M., Pintrich, P.R., Zeidner, M, “Handbook of self-regulation". San Diego: Elsevier Academic Press,(2000):256

18 Shelly E Tailor, "Psikologi Sosial”, Edisi 12, Jakarta: Kencana Prenada Media Group, (2009):133

19 Ferrari J. R., "Self Handicapping By Procrastinator : Academic Procrastination", http://www.carleton.cartpychyl/interner.html, diakses 28 Mei 2009
} 
jalannya rencana dan tindakan. Regulasi diri didefinisikan sebagai suatu proses di mana seseorang menghasilkan pikiran, perasaan dan tindakan, merencanakan dan mengadaptasikannya secara terus-menerus untuk mencapai tujuan-tujuan personal. Ia pun mengacu pada keterlibatan aktif seseorang dalam membuat tujuan, memantau dan mengevaluasi kemajuan dan, jika dibutuhkan, menyesuaikan strategi untuk mencapai tujuan.

Berdasarkan dari beberapa pengertian yang sudah di uraikan, dapat disimpulkan bahwa regulasi diri (self regulation) adalah kemampuan dalam mengontrol, mengatur, merencanakan, mengarahkan, dan memonitor perilaku untuk mencapai suatu tujuan tertentu dengan menggunakan strategi tertentu dan melibatkan unsur fisik, kognitif, motivasi, emosional, dan sosial.

Berdasarkan rumusan masalah penelitian ini, maka dirumuskan dua hipotesis dalam penelitian, yaitu hipotesis mayor dan hipotesis minor.

Hipotesis mayor penelitian ini adalah : ada hubungan antara konsep diri dan regulasi diri dengan Prokrastinasi Akademik Mahasiswa Fakultas Tarbiyah IAIN Sumatera Utara. Hipotesis minor penelitian ini adalah :

a) Ada hubungan antara konsep diri dengan prokrastinasi akademik mahasiswa Fakultas Ilmu Tarbiyah dan Keguruan IAIN Sumatera Utara.

b) Ada hubungan antara regulasi diri dengan prokrastinasi akademik Mahasiswa Fakultas Ilmu Tarbiyah dan Keguruan IAIN Sumatera Utara.

\section{METODE PENELITIAN}

Sehubungan dengan judul yang dinyatakan, jenis penelitian yang digunakan adalah penelitian kuantitatif dengan pendekatan deskriptif yang merupakan metode penelitian berdasarkan filosofi positivisme, digunakan untuk meneliti populasi atau sampel tertentu, mengumpulkan data dengan menggunakan instrumen penelitian, analisis kuantitatif / data statistik, untuk menguji hipotesis yang telah diterapkan. Penelitian ini menggunakan metode analisis regresi linier berganda karena variabel independen terdiri dari beberapa variabel.

Instrumen dalam Skala prokrastinasi akademik dalam penelitian ini disusun berdasarkan ciri-ciri prokrastinasi akademik yaitu: (a) penundaan untuk memulai dan menyelesaikan tugas, (b) keterlambatan dalam mengerjakan tugas, (c) kesenjangan waktu antara rencana dan kinerja aktual, dan (d) melakukan aktivitas yang lebih menyenangkan. Untuk instrument skala Alat ukur yang digunakan untuk mengukur konsep diri siswa menggunakan 
Tennessee Self Concept Scale (TSCS) oleh Williem H.Fitts (1971) yang dimodifikasi oleh Julia Raymond Lorenz (2002). Dan instrument untuk Regulasi diri diukur dengan menggunakan adaptasi dari Short Self-Regulation Questionnaire (SSRQ). Pengolahan data pada penelitian ini dilakukan dengan menggunakan program Microsoft Excel 2007 sebagai langkah awal pengumpulan data, kemudian menggunakan software pengolahan statistik SPSS versi IBM/IN, hakcipta (c) 2012, dilindungi UU yang dilakukan pada taraf signifikansi $(\alpha)=0,05$ untuk menguji validitas dan reliabilitas alat ukur, serta untuk melihat hubungan, dampak, atau pengaruh variabel tergantung, bebas, dan variabel moderator. Untuk teknik analisis data menggunakan analisis regresi berganda. Hal ini dikarenakan variabel yang diuji lebih dari 2.

\section{HASIL DAN PEMBAHASAN}

Pelaksanaan penelitian dilaksanakan pada tanggal 15 April sampai 16 April 2014 pada mahasiswa yang mengalami permasalah dalam perkuliahannya, yang berjumlah 77 orang. Selanjutnya pada tanggal 17 April 2014 dilakukan pengecekan dan sekaligus penyekoran terhadap skala yang telah terkumpul sehingga pada 18 April 2014 telah dapat dilanjutkan dengan pengolahan data guna mengetahui validitas dan reliabilitas skala.

Penelitian ini mengunakan sistem try out terpakai, artinya data yang sudah diambil dalam uji coba skala ukur, kembali digunakan sebagai data untuk pengujian hipotesis. Hal ini dilakukan sehubungan dengan terbatasnya jumlah subjek penelitian, Dengan catatan apabila data uji coba skala ukur tidak memenuhi persyaratan validitas dan reliabilitas, maka penelitian ini tidak dapat dilanjutkan.

Setelah melakukan pengujian Asumsi klasik dan semua data dinyakan normal, maka dilanjutkan dengan pengujian linieritas. Uji linieritas dilakukan untuk mengetahui apakah terdapat hubungan yang linier antara kedua variable penelitian. Hubungan yang linier menggambarkan bahwa perubahan pada variabel bebas akan cenderung diikuti oleh perubahan variabel tergantung dengan membentuk garis linier. Uji linieritas dilakukan untuk mengetahui apakah hubungan antara konsep diri dan regulasi diri dengan prokrastinasi akademik linier atau tidak. Hasil uji linieritas diketahui bahwa nilai p pada korelasional Y - $\mathrm{X}_{1}$ sebesar 0,000 dan korelasional $\mathrm{Y}-\mathrm{X}_{2}$ sebesar 0,000 sehingga dapat disimpulkan bahwa terdapat hubungan linier antara variabel konsep diri dan regulasi diri dengan prokrastinasi akademik. Hasil linier menunjukkan bahwa teknik regresi dapat digunakan untuk mengetahui hubungan antara 3 
variabel dan memprediksikan seberapa besar peran konsep diri dan regulasi diri dengan prokrastinasi akademik.

Analisis regresi linier berganda digunakan dalam penelitian ini dengan tujuan untuk mengujihipotesis mengenai hubungan variabel konsep diri dan regulasi diri dengan prokrastinasi akademik. Hasil pengolahan data dengan menggunakan program SPSS selengkapnya ada pada lampiran dan selanjutnya dijelaskan pada tabel berikut ini :

Tabel 1. Analisis Regresi Berganda

\section{Coefficients ${ }^{\mathrm{a}}$}

\begin{tabular}{|c|c|c|c|c|c|c|c|c|c|c|}
\hline \multirow[b]{2}{*}{ Model } & \multicolumn{2}{|c|}{$\begin{array}{c}\text { Unstandardized } \\
\text { Coefficients }\end{array}$} & \multirow{2}{*}{$\begin{array}{c}\begin{array}{c}\text { Standardiz } \\
\text { ed } \\
\text { Coefficient } \\
\text { s }\end{array} \\
\text { Beta }\end{array}$} & \multirow[b]{2}{*}{$\mathrm{t}$} & \multirow[b]{2}{*}{ Sig. } & $\begin{array}{r}95 \\
\text { Conf } \\
\text { Interv }\end{array}$ & $\begin{array}{l}0 \% \\
\text { dence } \\
1 \text { for B }\end{array}$ & \multicolumn{3}{|c|}{ Correlations } \\
\hline & $\mathrm{B}$ & $\begin{array}{l}\text { Std. } \\
\text { Error }\end{array}$ & & & & $\begin{array}{l}\text { Lower } \\
\text { Bound } \\
\end{array}$ & $\begin{array}{l}\text { Upper } \\
\text { Bound } \\
\end{array}$ & $\begin{array}{l}\text { Zero- } \\
\text { order }\end{array}$ & $\begin{array}{c}\text { Partia } \\
1\end{array}$ & Part \\
\hline $\begin{array}{l}1 \text { (Constan } \\
\text { t) }\end{array}$ & $\begin{array}{r}224.64 \\
8\end{array}$ & 10.252 & & 21.913 & .000 & $\begin{array}{r}204.22 \\
0\end{array}$ & $\begin{array}{r}245.07 \\
6\end{array}$ & & & \\
\hline $\mathrm{X} 1$ & -.495 & .150 & -.383 & -3.297 & .002 & -.794 & -.196 & -.732 & -.358 & -.238 \\
\hline $\mathrm{X} 2$ & -.507 & .132 & -.446 & -3.846 & .000 & -.770 & -.244 & -.746 & -.408 & -.278 \\
\hline
\end{tabular}

a. Dependent Variable: Y

Model persamaan regresi yang dapat dituliskan dari hasil tersebut dalam bentuk persamaan regresi sebagai berikut :

$Y=224.648-0,495 X_{1}-0,507 X_{2}$

Persamaan regresi tersebut dapat dijelaskan sebagai berikut :

a. Koefisien regresi variabel konsep diri mempunyai hubungan yang negatif dengan prokrastinasi akademik;

b. Koefisien regresi variabel regulasi diri mempunyai hubungan yang negatif dengan prokrastinasi akademik.

Pada tabel koefisien, pada kolom B pada konstanta (a) adalah 224,648, persepsi konsep diri $\left(\mathrm{X}_{1}\right)$ adalah -0,495 dan regulasi diri $\left(\mathrm{X}_{2}\right)$ adalah -0,507. Nilai korelasi parsial konsep diri $\left(\mathrm{X}_{1}\right)$ dengan prokrastinasi akademik (Y) sebesar -0,358 dengan $\mathrm{p}<0,05$, artinya terdapat korelasi yang negatif dan signifikan. Nilai tersebut menunjukkan bahwa arah hubungan kedua variabel negatif, artinya semakin tinggi konsep diri akan semakin rendah prokrastinasi akademik, hal itu berlaku pula sebaliknya, semakin semakin rendah konsep diri akan semakin tinggi prokrastinasi akademik, maka hipotesis 1 diterima. Untuk variabel regulasi diri $\left(\mathrm{X}_{2}\right)$ dengan prokrastinasi akademik (Y), nilai korelasi parsial sebesar -0.408 dengan $\mathrm{p}<0,05$ artinya terdapat korelasi yang 
negatif dan signifikan. Nilai tersebut menunjukkan bahwa arah hubungan kedua variabel negatif, artinya semakin tinggi regulasi diri akan semakin rendah prokratinasi akademik, hal itu berlaku pula sebaliknya, semakin semakin rendah regulasi diri akan semakin tinggi prokratinasi akademik,maka hipotesis 2 diterima.

Hasil Analisis Regresi Berganda juga menunjukkan bahwa terdapat pehubungan yang signifikan antara konsep diri $\left(\mathrm{X}_{1}\right)$ dan regulasi diri $\left(\mathrm{X}_{2}\right)$ dengan prokrastinasi akademik $(\mathrm{Y})$. Hal ini ditunjukan dengan nilai koefisien $F_{\text {reg }}=58,654$ dimana $p<0,05$. Dengan nilai signifikasi dibawah 0,05 menunjukkan bahwa secara bersama-sama konsep diri dan regulasi diri mempunyai korelasi yang signifikan dengan prokrastinasi akademik, maka hipotesis 3 diterima.

Tabel 2. Analisis regresi secara bersama-sama

\begin{tabular}{|c|c|c|c|c|c|c|}
\hline \multicolumn{7}{|c|}{ ANOVAa } \\
\hline \multicolumn{2}{|c|}{ Model } & $\begin{array}{l}\text { Sum of } \\
\text { Squares }\end{array}$ & df & $\begin{array}{c}\text { Mean } \\
\text { Square }\end{array}$ & $\mathrm{F}$ & Sig. \\
\hline \multirow[t]{3}{*}{1} & Regression & 36183.056 & 2 & 18091.528 & 58.654 & $.000^{\mathrm{b}}$ \\
\hline & Residual & 22825.074 & 74 & 308.447 & & \\
\hline & Total & 59008.130 & 76 & & & \\
\hline
\end{tabular}

a. Dependent Variable: Y

b. Predictors: (Constant), X2, X1

Uji F digunakan untuk mengetahui apakah variabel-variabel independen secara simultan berpengaruh signifikan terhadap variabel dependen. Derajat kepercayaan yang digunakan adalah 0,05. Apabila nilai $F$ hasil perhitungan lebih besar daripada nilai $F$ menurut tabel maka hipotesis alternatif, yang menyatakan bahwa semua variabel independen secara simultan berpengaruh signifikan terhadap variabel dependen. Outputnya sebagai berikut :

Uji F' menunjukan bahwa nilai $F_{\text {hitung }}$ sebesar 58.654 dengan tingkat (sig) 0.000 atau dapat nilai signifikansi 0.000 lebih kecil dari nilai probabilitas 0.005. Hal tersebut membuktikan bahwa terdapat pengaruh signifikan antara konsep diri dan regulasi diri terhadap prokrastinasi akademik atau Secara Simultan (bersama-sama) konsep diri dan regulasi diri signifikan terhadap prokrastinasi akademik"

Uji t digunakan untuk mengetahui apakah variabel-variabel independen secara parsial berpengaruh nyata atau tidak terhadap variabel dependen. Derajat signifikansi yang digunakan adalah 0,05. Apabila nilai signifikan lebih kecil dari derajat kepercayaan maka kita menerima 
hipotesis alternatif, yang menyatakan bahwa suatu variabel independen secara parsial mempengaruhi variabel dependen. Outputnya sebagai berikut :

Coefficientsa

\begin{tabular}{|c|c|c|c|c|c|c|c|c|c|c|}
\hline \multirow[b]{2}{*}{ Model } & \multicolumn{2}{|c|}{$\begin{array}{l}\text { Unstandardized } \\
\text { Coefficients }\end{array}$} & \multirow{2}{*}{$\begin{array}{c}\begin{array}{c}\text { Standardiz } \\
\text { ed } \\
\text { Coefficient } \\
\text { s }\end{array} \\
\text { Beta } \\
\end{array}$} & \multirow[b]{2}{*}{$\mathrm{t}$} & \multirow[b]{2}{*}{ Sig. } & \multicolumn{2}{|c|}{$\begin{array}{c}95.0 \% \\
\text { Confidence } \\
\text { Interval for B }\end{array}$} & \multicolumn{3}{|c|}{ Correlations } \\
\hline & B & $\begin{array}{l}\text { Std. } \\
\text { Error }\end{array}$ & & & & $\begin{array}{l}\text { Lower } \\
\text { Bound }\end{array}$ & $\begin{array}{l}\text { Upper } \\
\text { Bound }\end{array}$ & $\begin{array}{l}\text { Zero- } \\
\text { order }\end{array}$ & $\begin{array}{c}\text { Partia } \\
1\end{array}$ & Part \\
\hline $\begin{array}{ll}1 & \text { (Constan } \\
\text { t) }\end{array}$ & $\begin{array}{r}224.64 \\
8\end{array}$ & 10.252 & & 21.913 & .000 & $\begin{array}{r}204.22 \\
0\end{array}$ & $\begin{array}{r}245.07 \\
6\end{array}$ & & & \\
\hline $\mathrm{X} 1$ & -.495 & .150 & -.383 & -3.297 & .002 & -.794 & -.196 & -.732 & -.358 & -.238 \\
\hline $\mathrm{X} 2$ & -.507 & .132 & -.446 & -3.846 & .000 & -.770 & -.244 & -.746 & -.408 & -.278 \\
\hline
\end{tabular}

a. Dependent Variable: Y

Hasil yang diperoleh dari penelitian menunjukkan bahwa konsep diri dan regulasi diri memiliki hubungan negatif yang signifikan dengan prokrastinasi akademik dalam penyelesaian beban kuliah pada mahasiswa fakultas Ilmu Tarbiyah dan Keguruan. Hal ini ditunjukkan dengan nilai koefisien $\mathrm{F}_{\text {reg }}=58,654$ dimana $\mathrm{p}<0,05$. Ini menandakan konsep diri dan regulasi diri berhubungan signifikan dengan prokrastinasi akademik, semakin tinggi nilai konsep diri dan regulasi diri maka prokrastinasi akademik akan semakin rendah. Sebaliknya semakin rendah nilai konsep diri dan regulasi diri maka prokrastinasi akademik akan semakin tinggi.

Selain itu terdapat juga hasil penelitian yang telah dilakukan menunjukkan nilai koefisien determinan sebesar 0,603 yang artinya variabel prokrastinasi akademik dapat dibentuk oleh variabel konsep diri dan regulasi diri adalah sebesar $60.3 \%$, sedangkan masih terdapat 39,7\% $(100 \%$ - 60,3\%) variabel bebas lainnya yang mempunyai hubungan dengan prokrastinasi akademik namun belum terdapat dalam penelitian ini.

Berdasarkan hal inilah yang menunjukkan bahwa konsep diri dan regulasi diri mempunyai hubungan signifikan negatif, yang mana apabila konsep diri dan regulasi diri mahasiswa baik atau tinggi secara otomatis mahasiswa akan rendah. dan apabila konsep diri dan regulasi diri mahasiswa buruk/rendah, maka prokrastinasi tinggi. Sesuai dengan yang disampaikan oleh Menurut Calhoun dan Acocella dalam (Fasti Rola, 2006) , dalam perkembangannya konsep diri terbagi dua, yaitu konsep diri positif dan konsep diri negatif. Individu yang memiliki konsep diri positif akan merancangn tujuan-tujuan yang sesuai dengan 
realitas, yaitu tujuan yang memiliki kemungkinan besar untuk dapat dicapai, mampu menghadapi kehidupan di depannya serta menganggap bahwa hidup adalah sutu proses penemuan. Menurut William D.Brooks (dalam Rahkmat, 2005) bahwa dalam menilai dirinya seseorang ada yang menilai positif dan ada yang menilai negatif. Maksudnya individu tersebut ada yang mempunyai konsep diri yang positif dan ada yang mempunyai konsep diri yang negatif. Bagi mahasiswa yang memiliki konsep diri positif, dalam penelitian ini dapat dipaparkan akan memperoleh keberhasilan akademik yang baik dan bagi yang memiliki konsep diri negatif, hal inilah yang dialami sebagian besar sampel dalam penelitian ini. Kemudian dalam penelitian ini juga dapat dijelaskan bahwa Regulasi diri adalah kontruk psikologis penting yang baru muncul dalam literatur psikologi di Indonesia. Jika di Barat perkembangan regulasi diri telah dimulai sejak sekitar 30 tahun yang lalu, tidak demikian halnya dengan yang terjadi di Indonesia. Penelitian pertama yang peneliti temukan bersangkutan dengan regulasi diri adalah disertasi Markum (1998) yang menunjukkan bahwa individu yang berprestasi tinggi memiliki karakteristik pekerja keras, disiplin, prestatif, berkomitmen, mandiri, dan realistis. Sekalipun tidak secara langsung berbicara tentang regulasi diri, penemuan tersebut mengindikasikan adanya peran self-regulatory ability bagi keberhasilan seseorang. jadi berdasarkan dari beberapa penelitian terdahulu, menyatakan regulasi diri akan menentukan keberhasilan seseorang dalam mengatur dirinya baik dalam penundaan suatu pekerjaan khususnya pada bidang akademik. Sehingga prokrastinasi yang tinggi dipengaruhi oleh regulasi diri yang rendah.

\section{SIMPULAN}

Berdasarkan hasil-hasil yang telah diperoleh dalam penelitian ini, maka dapat disimpulkan hal-hal sebagai berikut: Terdapat hubungan yang signifikan antara Konsep Diri dan Regulasi Diri dengan prokrastinasi akademik. Hal ini ditunjukkan dengan koefisien $\mathrm{F}_{\text {reg }}=58,654$ dimana $\mathrm{p}<0,05$. Ini menandakan Konsep Diri dan Regulasi Diri berhubungan signifikan dengan prokrastinasi akademik, semakin tinggi nilai Konsep Diri dan Regulasi Diri maka prokrastinasi akademik akan semakin rendah. Sebaliknya semakin rendah nilai Konsep Diri dan Regulasi Diri,, maka prokrastinasi akademik akan semakin tinggi. 


\section{DAFTAR PUSTAKA}

Boekaerts, M., Pintrich, P.R., Zeidner, M, “Handbook of self-regulation”. San Diego: Elsevier Academic Press,(2000):256

Brooks, W. D , "Speech Communication", Dubuque: Wm. C. Brown Company Publishers. (1974) : 40

Clemes, H., Bean, R, "Membangkitkan Harga Diri Anak, Alih bahasa: Anton Adiwiyoto", Jakarta: Mitra Utama. (2001):2.

Colhoun, J.F. \& Ococella, J.R, "Psychology of Adjusment an Human Relationship", Terj. Satmiko, R.S Semarang : IKIP Semarang Press, (1990):67.

Diaz, R.M, Neal, C. J, \& Amaya-Williams, M, "The social origins of selfregulation", Dalam L.C. Moll (Ed). Vygotsky and education: instructional implications of sociohistorical psychology (pp 127-154). Victoria: Cambridge University Press, (1990):130

Ferrari J. R., "Self Handicapping By Procrastinator : Academic Procrastination", http://www.carleton.cartpychyl/interner.html, diakses 28 Mei 2009

Friedman, Howard S \& schustack, Miriam W. "Kepribadian Teori Klasik Dan Riset Modern”, Edisi 3. Erlangga, (2006):276

Ji Won You. Examining the Effect of Academic Procrastination on Achievement Using LMS Data in e-Learning.Journal of Educational Technology and Society, Vol. 18, No. 3 (2015):64-74

Milgram, N, Procrastination, Encyclopedy of Human Biology, New York: Academic Press, (1991):57.

Prayitno, Keterampilan Belajar, Tim Pengembangan 3 SCPD Proyek PGSM. Depdikbud, Jakarta (2002): 62.

Randy Moore, Academic Procrastination and Course Performance among Developmental Education Students, Journal Research and Teaching in Developmental Education, Vol. 24, No. 2 (2008):56-67.

Santrock, W. J, “Adolescence: Perkembangan Remaja, Terjemahan oleh Shinto B. Adelar \& Sherly Saragih", Jakarta : Erlangga, (2003) : 56.

Schunk, D.H, “Teori-teori pembelajaran: perspektif pendidikan”, (terjemahan Eva Hamdiah \& Rahmat Fajar). Yogayakarta: Pustaka, (2012): 560

Shelly E Tailor, "Psikologi Sosial", Edisi 12, Jakarta: Kencana Prenada Media Group, (2009):133 
Surijah, E, \& Sia, T, "Mahasiswa Versus Tugas : Prokrastinasi Akademik Dan Conscientiousness", Anima, Indonesian Psychological Journal, Vol. 22, No. 4, (2007): 356.

Surya, H, "Percaya Diri itu Penting : Peran Orangtua dalam Menumbuhkan Percaya Diri Anak", Jakarta : Elex Media Komputindo (2007):3.

Syaiful Indra, Efektifitas Team Assisted Individualization untuk Mengurangi Prokrastinasi Akademik, Jurnal Edukasi, Vol I, Nomor 2, (Juli 2015):175 